\title{
Impact of Climate Change on Agriculture and Its Mitigation Strategies: A Review
}

\author{
Gurdeep Singh Malhi ${ }^{1}$, Manpreet Kaur ${ }^{2}$ and Prashant Kaushik ${ }^{3,4, *}$ \\ 1 Department of Agronomy, Punjab Agricultural University, Ludhiana 141004, Punjab, India; \\ 89gurdeep.malhi@gmail.com \\ 2 Department of Agricultural Economics, CCS Haryana Agricultural University, Hisar 125004, Haryana, India; \\ mkaur2515@gmail.com \\ 3 Instituto de Conservación y Mejora de la Agrodiversidad Valenciana, Universitat Politècnica de València, \\ 46022 Valencia, Spain \\ 4 Nagano University, 1088 Komaki, Ueda, Nagano 386-0031, Japan \\ * Correspondence: prakau@doctor.upv.es; Tel.: +34-963-877-000
}

\section{check for}

updates

Citation: Malhi, G.S.; Kaur, M.; Kaushik, P. Impact of Climate Change on Agriculture and Its Mitigation Strategies: A Review. Sustainability 2021, 13, 1318. https://doi.org/ $10.3390 /$ su13031318

Academic Editor: Jun-Ichi Sakagami Received: 26 December 2020

Accepted: 22 January 2021

Published: 27 January 2021

Publisher's Note: MDPI stays neutral with regard to jurisdictional claims in published maps and institutional affiliations.

Copyright: (c) 2021 by the authors. Licensee MDPI, Basel, Switzerland. This article is an open access article distributed under the terms and conditions of the Creative Commons Attribution (CC BY) license (https:/ / creativecommons.org/licenses/by/ $4.0 /)$.

\begin{abstract}
Climate change is a global threat to the food and nutritional security of the world. As greenhouse-gas emissions in the atmosphere are increasing, the temperature is also rising due to the greenhouse effect. The average global temperature is increasing continuously and is predicted to rise by $2{ }^{\circ} \mathrm{C}$ until 2100 , which would cause substantial economic losses at the global level. The concentration of $\mathrm{CO}_{2}$, which accounts for a major proportion of greenhouse gases, is increasing at an alarming rate, and has led to higher growth and plant productivity due to increased photosynthesis, but increased temperature offsets this effect as it leads to increased crop respiration rate and evapotranspiration, higher pest infestation, a shift in weed flora, and reduced crop duration. Climate change also affects the microbial population and their enzymatic activities in soil. This paper reviews the information collected through the literature regarding the issue of climate change, its possible causes, its projection in the near future, its impact on the agriculture sector as an influence on physiological and metabolic activities of plants, and its potential and reported implications for growth and plant productivity, pest infestation, and mitigation strategies and their economic impact.
\end{abstract}

Keywords: climate change; climate-smart agriculture; diseases; economics; pest; weeds

\section{Introduction}

Climate change is one of the biggest challenges to the world in present times. It is defined as significant changes in the average values of meteorological elements, such as precipitation and temperature, for which averages have been computed over a long period [1]. The past few decades indicate that significant changes in climate at a global level were the result of enhanced human activities that altered the composition of the global atmosphere [2]. The concentration of greenhouses gases such as methane $\left(\mathrm{CH}_{4}\right)$, carbon dioxide $\left(\mathrm{CO}_{2}\right)$, and nitrous oxide $\left(\mathrm{N}_{2} \mathrm{O}\right)$ have been increased by $150 \%, 40 \%$ and $20 \%$, respectively since 1750 [3]. Carbon dioxide emissions, which account for the maximum proportion of greenhouse gases [4], rose to 36.14 billion metric tons in 2014 from 22.15 billion metric tons in 1990 [5]. The average global temperature has increased at an average rate of $0.15-0.20^{\circ} \mathrm{C}$ per decade since 1975 [6], and is expected to increase by $1.4-5.8^{\circ} \mathrm{C}$ by 2021 [7]. Greenhouse gas (GHG) emissions, particularly $\mathrm{CO}_{2}$ from the combustion of fossil fuels and non- $\mathrm{CO}_{2}$ GHGs such as nitrous oxide, methane, and CFCs add to global warming. The $\mathrm{CO}_{2}$ concentration in the atmosphere had increased to $411.43 \mathrm{ppm}$ in 2019 from $315.98 \mathrm{ppm}$ in 1959, as shown in Figure 1 [8]. $\mathrm{CO}_{2}$ constitutes a major proportion of greenhouse gases in the atmosphere: $65 \%$ from fossil fuels and industrial processes and $11 \%$ from forestry and other land use, followed by methane $(16 \%)$, nitrous oxide $(6 \%)$, and fluorinated gases $(2 \%)$ [3]. Before 1750, $\mathrm{CO}_{2}$ emissions from fossil fuels was negligible, but it increased 
rapidly with industrialization. Figure 2 shows the increase in $\mathrm{CO}_{2}$ emissions over the years (1850-2020). The world has emitted around 1.5 trillion metric tons of $\mathrm{CO}_{2}$ since 1751 . However, there are regional variations in the emission. Europe is the largest contributor of $\mathrm{CO}_{2}$ having around 514 billion metric tons of $\mathrm{CO}_{2}$ emissions, followed by Asia and the North American continent, which have recorded cumulative $\mathrm{CO}_{2}$ emissions of 457 billion metric tons each. The USA is the largest contributor to $\mathrm{CO}_{2}$ emissions (399 billion metric tons), and has contributed $25 \%$ of total historical emissions since 1751 , followed by China (200 billion metric tons). The European Union (EU-28), a union of 28 countries that sets collaborative targets, has contributed $22 \%$ of historical emissions of $\mathrm{CO}_{2}$. Africa contributes only $3 \%$ of global cumulative $\mathrm{CO}_{2}$ emissions due to low per-capita emissions. However, countries like Brazil and India, whose historical emission is less, significantly add to the total emissions in the current context [9]. With an increased level of $\mathrm{CO}_{2}$ in the atmosphere, the fertilization of crops is increased along with decreased energy requirements due to warming. These are certain positive impacts of climate change, whereas water resources are negatively impacted due to climate change. In the 20th century, the impact of climate change was mainly positive. Most countries were benefitted until 1980, after which the trend remained the same for the developed world, while the Third-World countries were negatively impacted. In the 21st century, climate change will become a severe problem, and both rich and developing countries will face negative externalities [10].

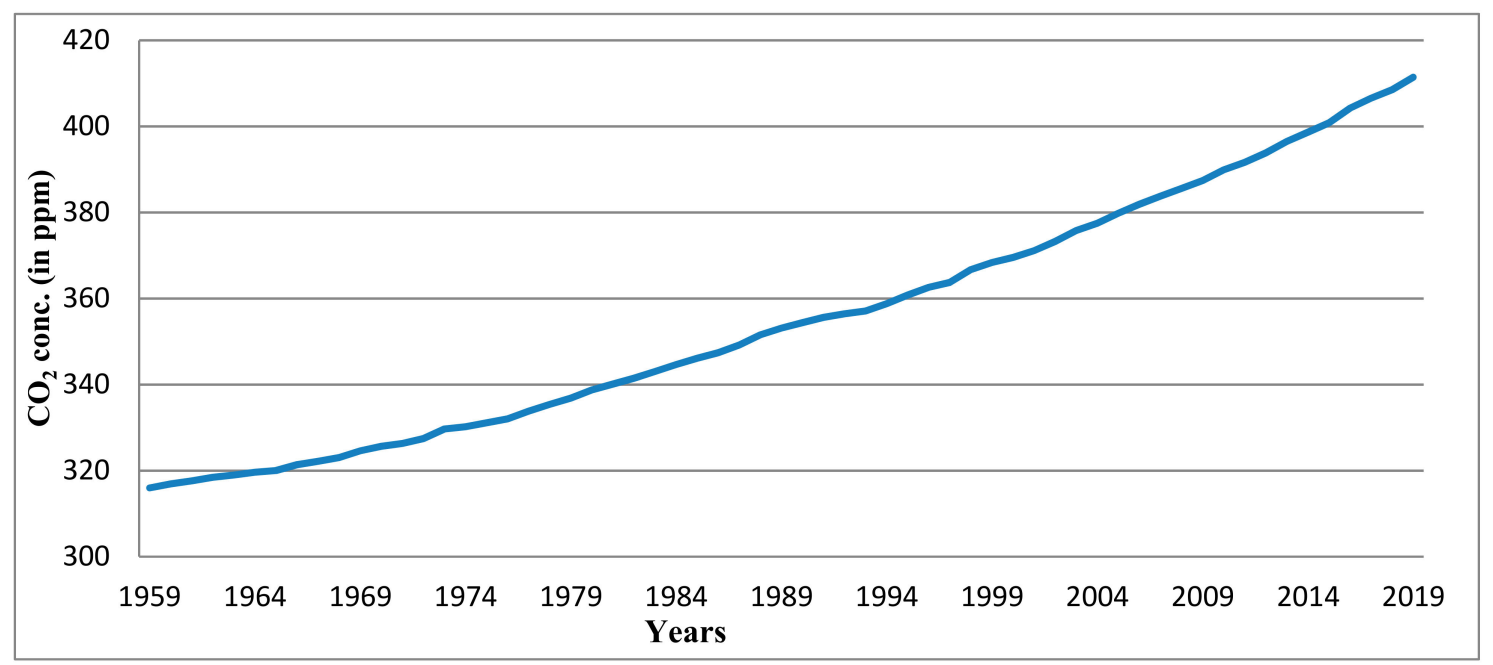

Figure 1. The increase in $\mathrm{CO}_{2}$ concentration in the atmosphere (source: [8]).

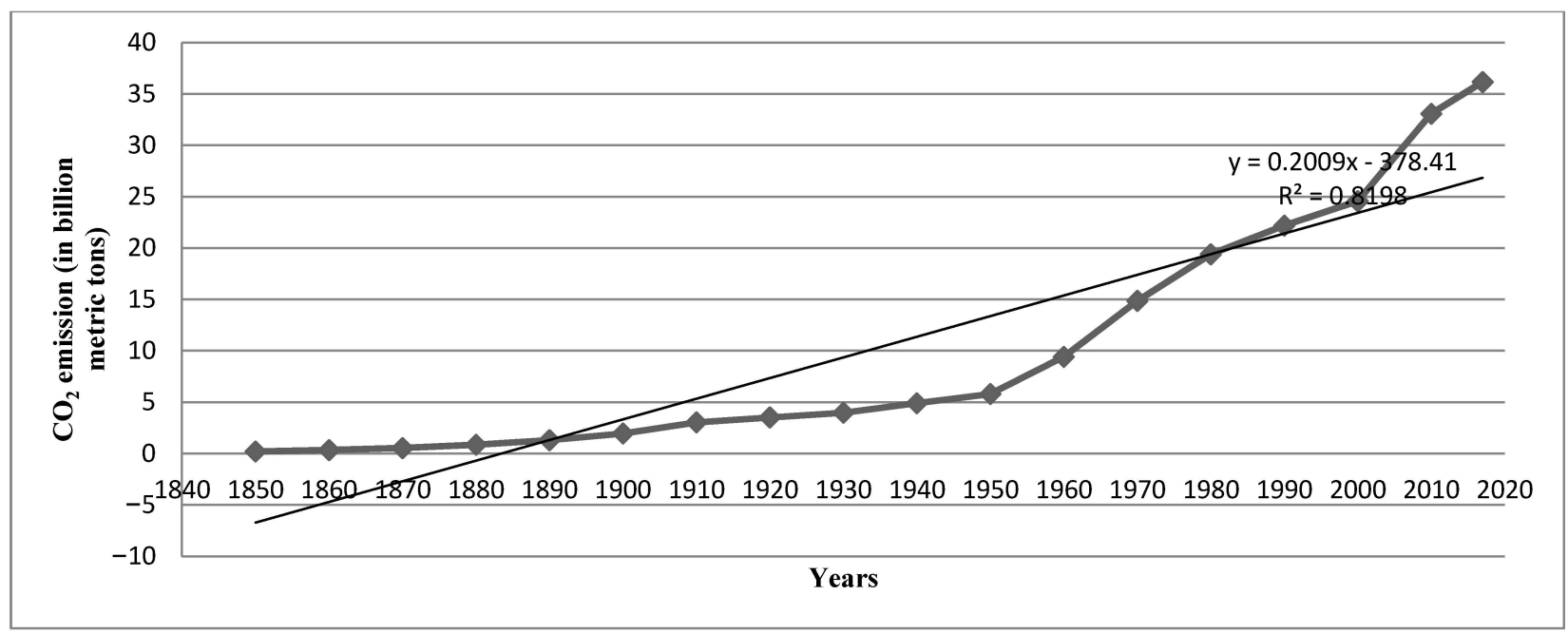

Figure 2. $\mathrm{CO}_{2}$ emission in the atmosphere over the years (1850-2020) (Source: [11]). 
The rise in greenhouse gases has implications for the rising temperature of the atmosphere. These infrared active gases, mainly carbon dioxide $\left(\mathrm{CO}_{2}\right)$, ozone $\left(\mathrm{O}_{3}\right)$, and water vapor $\left(\mathrm{H}_{2} \mathrm{O}\right)$, absorb the thermal radiations emitted by the atmosphere and the surface of the earth, which in turns warms the earth. This phenomenon is known as the greenhouse effect. The average global temperature anomaly is shown in Figure 3, and illustrates a significant increase in the global temperature compared to the average temperature of the base period (1901-2000). The global average temperature has been increased in the range of $1-1.2{ }^{\circ} \mathrm{C}$ since 1850 . Still, since the temperature changes in landmasses are much more prominent, the global land temperature has increased around twice that of the oceans. The temperature of land across the world has risen by $1.32 \pm 0.04{ }^{\circ} \mathrm{C}$ compared to the 1951-1980 average, while the increase was $0.59 \pm 0.06^{\circ} \mathrm{C}$ for the ocean surface temperature (excluding areas of sea ice). Moreover, since the Northern Hemisphere constitutes the larger portion of landmasses, it has shown a higher average temperature than the Southern Hemisphere. The temperature of the Northern Hemisphere and the Southern Hemisphere has risen $1.31^{\circ} \mathrm{C}$ and $0.91^{\circ} \mathrm{C}$, respectively, with a global average of $1.11^{\circ} \mathrm{C}$ since 1850 . The extreme rise in temperature has been observed in the polar regions, and has detrimental effects, like glacial melting [12]. As the global temperature is rising, there is a need to reduce greenhouse-gas emissions to limit the temperature increase of $2{ }^{\circ} \mathrm{C}$ relative to pre-industrialization. The developed countries have around a $60-80 \%$ contribution to the global temperature rise, sea-ice reduction, and upper-ocean warming, compared to $20-40 \%$ for developing countries, since 2005 [13]. The average global temperature is expected to rise by $2{ }^{\circ} \mathrm{C}$ by 2100 and $4.2{ }^{\circ} \mathrm{C}$ by 2400 , as predicted by probabilistic computations of the IPCC's range of climate sensitivity. However, surpassing $2{ }^{\circ} \mathrm{C}$ by 2100 at the present radiative-force level does not seem likely to happen. But the risk is increasing, mainly due to the stabilizing of radiative forces above $400 \mathrm{ppm}$ of $\mathrm{CO}_{2}$. Moreover, it is exceptionally unlikely that the temperature will rise by $2{ }^{\circ} \mathrm{C}$ if anthropogenic emissions were ceased tomorrow [14].

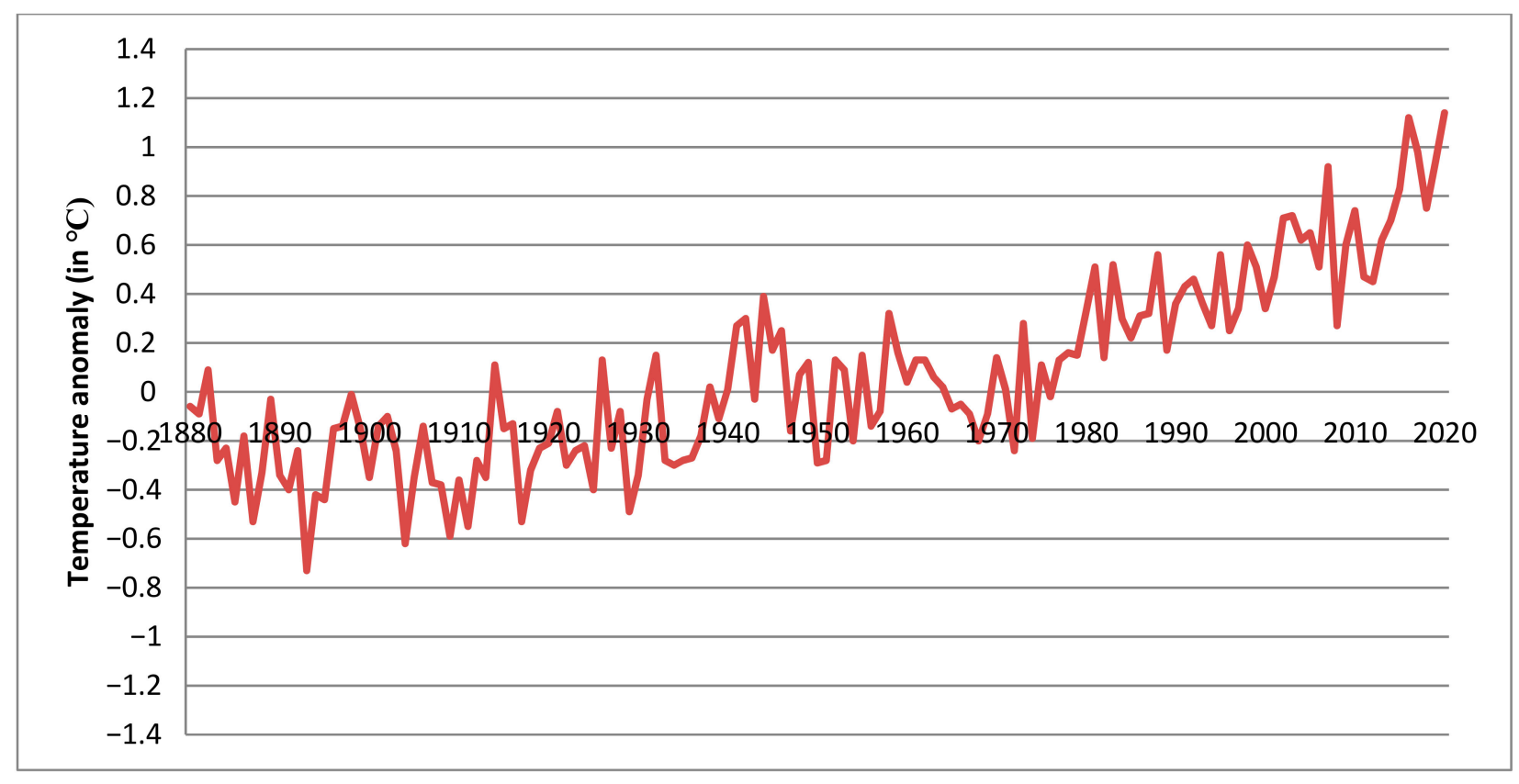

Figure 3. Global land and ocean temperature anomalies over the base period (1901-2000) (source: [15]).

Climate change is projected to worsen in the upcoming future. In the Punjab province of Pakistan, there have been projections of increased minimum and maximum temperature in the Kharif and rabi seasons. In Kharif season, the average maximum temperature and average minimum temperature is predicted to rise by $1-3.3^{\circ} \mathrm{C}$ and $2-3{ }^{\circ} \mathrm{C}$; while in rabi, it is projected to increase by $2.1-3.5^{\circ} \mathrm{C}$ and $2-3{ }^{\circ} \mathrm{C}$, respectively, in simulations done for 
the future mid-century (2040-2069). There have also been projections of variations in the regions' rainfall, more emphatically during the Kharif season (25-35\%); while in the rabi season, the variations are minimal [16]. The temperature minimums and maximums are also projected to rise in Punjab, India by the middle and end of the 21st century, as estimated by PRECIS (Providing Regional Climates for Impact Studies). Moreover, extreme incidences of high temperature (heat waves) during March to June and low temperatures during December and January (frost) are also predicted [17] The extremes in weather parameters, mainly minimum temperature, maximum temperature, and precipitation, are also projected to be observed more frequently, with higher intensity in China, with additional warming of $0.5^{\circ} \mathrm{C}$. Moreover, if global warming is kept below $1.5^{\circ} \mathrm{C}$, the weather extremes will be lowered [18].

The global precipitation anomalies over the base period (1901-2000) are shown in the Figure 4, which shows that the precipitation change is showing a positive trend, but these vary according to the region. There was an absolute change of 0.78 inches in precipitation across the world from 1901 to 2015 [11]. However, temperature and precipitation extremes are more likely to be witnessed in the near future due to global warming. Extreme precipitation phenomena, either heavy rainfall or drought, are dependent on a region's geography. Increased average river flows due to prolonged heavy rainfall are more likely to be observed in South and East Asia, while the drought in southern Africa and South America will be less severe. The rainfall pattern of the Indus river basin is projected to show uneven variations spatially and seasonally. Precipitation is predicted to rise in the upper Indus basin, while the same has been projected to decrease in the lower basin. Moreover, the upper basin is also projected to face increased warming than the lower basin [19]. There is a probability of more warm extremes, lesser cold extremes, and more strengthened precipitation extremes in the future period in the northeastern United States. Higher emissions will intensify these changes [20]. The increased intensity and frequency of precipitation also impacts soil erosion, and will have more adverse consequences in northeast China if greenhouse-gas emissions increase [21]. Precipitation anomalies have detrimental effects on agriculture, mainly in developing nations. Apart from affecting crop yields, it significantly influences cropland areas. There is evidence suggesting that the approximately $9 \%$ rate of cropland expansion in the developing world over the last two decades is due to dry anomalies as farmers expand the area to compensate for yield losses [22]. Global warming will pose a severe threat to the world's food security, but if it is limited to $1.5^{\circ} \mathrm{C}$, the $76 \%$ developing countries' vulnerability will be reduced compared with the same regions at $2{ }^{\circ} \mathrm{C}$ [23]. Ensuring food for the world's population in the face of climate change is not an easy task, owing to its huge impact on agriculture production [24]. There must be an annual increase in the world's agricultural production by $60 \%$ from $2005 / 2007$ to 2050 , comprising a rise of $77 \%$ in developing and $24 \%$ in developed countries, to fulfill the food and nutritional requirements of the population by 2050 [25]. Climate change is known to have an adverse effect on agricultural production, and is projected to reduce the global cereal production of maize and wheat by $3.8 \%$ and $5.5 \%$, respectively [26]. Because of climatic factors, plants have to face several abiotic stresses such as salinity, drought, heat stress, cold stress, etc. [27]. Shortage of water availability, soil fertility loss, and pest infestations in crops are the significant undesirable impacts of climate change [28]. This review is an attempt to consolidate the studies related to the impact of climate change on crop yields, associated weed infestations, and economic consequences for 1998-2020. Moreover, mitigation and adaptation strategies to combat climate change are also discussed to reach a clear understanding of their possible significance. 


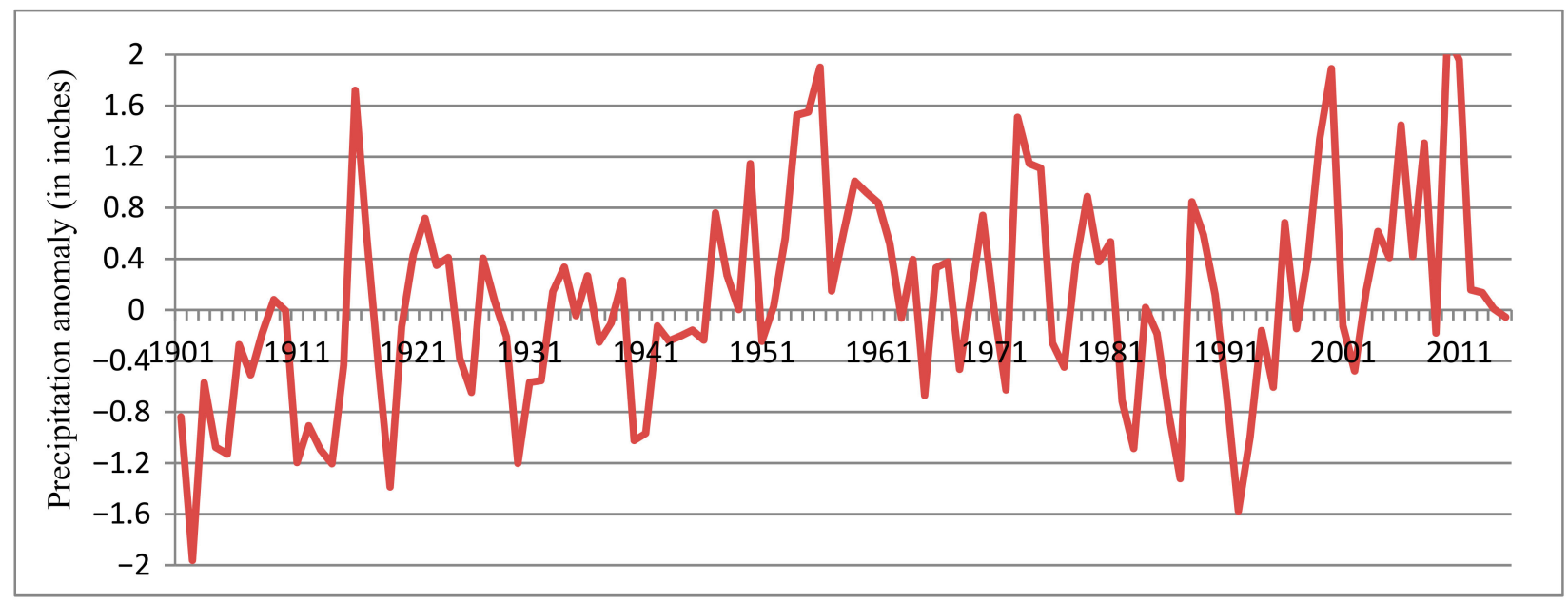

Figure 4. Global precipitation anomalies over the base period (1901-2000) (source: [11]).

\section{Materials and Methods}

A systematic review of the literature was done through PRISMA (Preferred Reporting Items for Systematic Meta-Analysis), as shown in Figure 5 [29,30]. The studies related to the research goals were searched on Google Scholar using the following keywords: climate and agriculture; mitigation and climate change; climate change and economics; mitigation and economics. Moreover, the search was performed for the years 1998-2020. A total of 410 documents were screened, out of which 200 papers were found to be relevant. Research papers published in journals having an impact factor were finally selected, and their results are reported here.

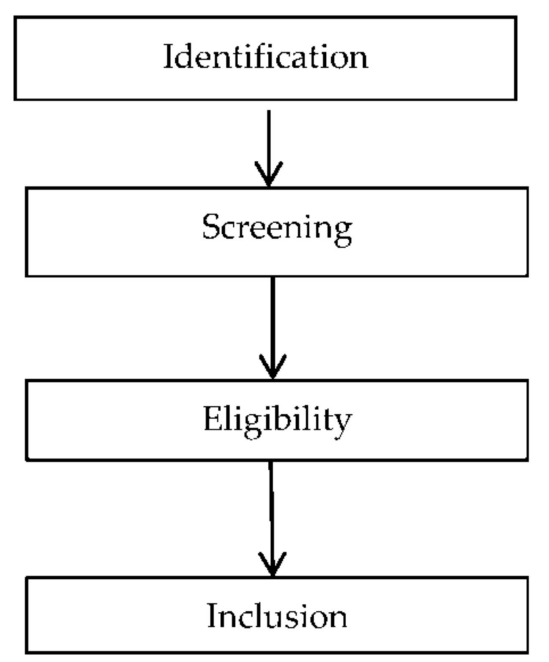

Research databases were searched on Google scholar using keywords (410)

Documents relevant to the study and published in journals having impact factor (200)

Documents removed: (67)

- having duplicate information

- not related to the agriculture specifically

Documents included: 133

Figure 5. Method for selection of research papers for review and analysis.

\section{Causes of Climate Change}

Temperature changes are caused by natural phenomena and anthropogenic activities on earth, which ultimately initiates the concentration of GHGs [31]. Anthropogenic activities lead to the emission of greenhouse gas such as $\mathrm{CO}_{2}$, methane, and nitrous oxide, as well as other substances that lead to ozone depletion in the atmosphere [32]. The increased $\mathrm{CO}_{2}$ concentration in the atmosphere can affect microbial activities in the soil, along with implications on water content, and therefore increased atmospheric $\mathrm{CO}_{2}(463-780 \mathrm{ppm}) \mathrm{can}$ stimulate nitrous oxide and methane emission from upland soil and wetlands, respectively, which nullifies the $16.6 \%$ mitigation effect of climate change as predicted by increasing ter- 
restrial carbon sink [33]. The agriculture sector contributes $15 \%$ of total emissions, primarily methane and nitrous oxide. The global emission of non-agricultural greenhouse gases is predicted to rise until 2055 if the dietary preferences and consumption of food energy are kept constant at 1995 levels. However, with changing preferences toward high-value foods such as milk and meat, the emissions are predicted to rise at an even higher rate. The emission can be reduced either with technological mitigation or by reduced meat consumption, or both [34]. The livestock sector is the main contributor to greenhouse-gas emissions, and according to the IPCC, it generates around $8-10.8 \%$ of emissions; however, it can contribute up to $18 \%$ of GHG emissions based on lifecycle analysis [35]. The main sources of greenhouse-gas emissions by the livestock sectors include enteric fermentation, $\mathrm{N}_{2} \mathrm{O}$ emissions, liming, fossil fuels, organic farming, and fertilizer production [36]. The use of nitrogenous chemical fertilizers also leads to greenhouse-gas emissions [37]. With better management of crop production, $\mathrm{N}$ fertilizer use can be lowered by $38 \%$. Better crop management also leads to consumption of $11 \%$ less input energy with $33 \%$ increased yields, leading to a reduction in greenhouse-gas emissions by $20 \%$ [38].

\section{Climate Change and Agriculture}

Agriculture is the most vulnerable sector to climate change, owing to its huge size and sensitivity to weather parameters, thereby causing huge economic impacts [39]. The changes in climatic events such as temperature and rainfall significantly affect the yield of crops. The effect of rising temperatures, precipitation variation, and $\mathrm{CO}_{2}$ fertilization varies according to the crop, location, and magnitude of change in the parameters. The temperature increase is found to reduce the yield, while the precipitation increase is likely to offset or reduce the impact of increasing temperature [40]. As influenced by climatic variables when witnessed in Iran, crop productivity depends on adaptation abilities and crop type, climate scenario, and $\mathrm{CO}_{2}$ fertilization effect [41]. The net revenue of farmers is found to decrease significantly with a decrease in precipitation or increase in temperature in Cameroon. This factor and poor policy-making have led to low demand for Cameroon's agricultural exports, thereby causing fluctuations in national income [42]. Statistical evidence shows the temperature affects coffee yield in Veracruz, Mexico. It was also found that coffee production may not remain economically viable for the producers in the coming years, as there is an indication of a $34 \%$ reduction in current production [43]. The effect of climate change on the crop yields vary according to the area and irrigation application. Crop yields can be increased by expanding irrigated areas, which can have a detrimental effect on the environment [44]. The rise in temperature is likely to reduce the yield of many crops by reducing their duration [45]. The aggregate production of wheat, rice, and maize is expected to decrease if both the temperate and tropical regions experience a warming of $2{ }^{\circ} \mathrm{C}$ [46]. Climate change in general has more impact on tropical regions, as tropical crops remain closer to their high-temperature optima, and thereby experience high-temperature stress during elevated levels of temperature.

Moreover, insect pests and diseases are more prevalent in humid and warmer regions [47]. Other parameters such as humidity and wind speed, along with temperature and rainfall, also impact crop yields, and in the absence of these parameters, there has been a chance of over-prediction of the cost of climate change. Moreover, it was found that climate change is likely to reduce the yields of wheat, corn, and rice in China by $18.26 \pm 12.13,45.10 \pm 11.55$, and $36.25 \pm 10.75 \%$ until 2100 [48]. Extreme weather events have become more frequent since the 1900s in the Netherlands, and have significantly affected the wheat yield in the Dutch region. The week in which an extreme weather event occurred determined the extent of yield reduction in wheat [49]. There has been a projection of higher droughts in the near future due to climate change in most of the regions of the world, and an increase of drought-affected area from 15.4 to $44.0 \%$ is projected by 2100. Africa is cited as the most vulnerable area. The yield of major crops in drought areas is expected to be reduced by more than $50 \%$ by 2050 and by almost $90 \%$ by 2100 [50]. 
The loss of crop yields can increase food prices, and can have an absurd effect on agriculture welfare globally, with a $0.3 \%$ annual loss of future GDP globally by 2100 [51]. However, [52] found that climate change has limited influence on the world food supply, but the developing countries will face severe negative consequences. In India, the temperature is predicted rise between $2.33^{\circ} \mathrm{C}$ and $4.78^{\circ} \mathrm{C}$ along with a doubling of $\mathrm{CO}_{2}$ concentration and longevity of heat waves, which could have a detrimental effect on the agriculture sector [53]. In the arid region of Rawalpindi, Pakistan, an annual loss of INR $4180 /$ acre is to be borne by farmers by 2100 with a $1{ }^{\circ} \mathrm{C}$ increase in temperature, while the net revenue can be increased by INR 377.4 and INR 649.21 with an increase in rainfall of $8 \%$ and $14 \%$, respectively [54]. The yield losses in three cereal grains (rice, maize, and wheat) are projected to worsen by 10 to $25 \%$ with a $1{ }^{\circ} \mathrm{C}$ increase in mean surface temperature globally [55]. In sub-Saharan Africa, the average crop yield is projected to be reduced by $6-24 \%$ due to climate change [56]. The total fish demand in Solomon Island is also projected to exceed the production in 2050, which will have serious implications for food security, as per-capita consumption will be reduced [57].

Plant-water relations are highly susceptible to changes in temperature and precipitation, and physiological changes are more likely to be impacted by extreme changes in these parameters than by changes in mean climate [58]. Plants' response to climate change varies according to the plant species and developmental stage of the plant. There are species-specific thresholds for different plants, and their responses, such as elongation of roots, disturbance in growth angle of roots, and reduction in yield, vary among different species of plants [59]. With increased $\mathrm{CO}_{2}$ content in the atmosphere, reduced transpiration was found in plants, leading to an increase in air temperature of $0.42 \pm 0.02 \mathrm{~K}$. This indirect physiological effect of raised $\mathrm{CO}_{2}$ and a direct radiative effect can increase warming of land surfaces by $3.33 \pm 0.03 \mathrm{~K}$ [60]. With a rising $\mathrm{CO}_{2}$ level in the atmosphere, the harvestable produce of crops are expected to increase, and the developmental changes in plants depend upon the type of crops. $C_{3}$ crops are expected to produce more, however, the water requirements of both $C_{3}$ and $C_{4}$ crops are expected to be lowered in the absence of stressful conditions. But these beneficial impacts of raised $\mathrm{CO}_{2}$ are likely to be offset by elevated temperatures and altered precipitations [61].

However, a positive impact of climate change on agriculture production is also observed in some areas. But these regional changes, whether increases or decreases, would not result in massive changes, and these changes will be more prominent in some low latitudes only. However, if the temperature is increased beyond that equivalent to doubled $\mathrm{CO}_{2}$, this can cause substantial economic losses [62]. The detrimental impact of climate change will be enormous in developing countries' tropical regions, but it will largely depend on the region's climate scenario. The drier region of Sri Lanka (north and east) will experience huge losses in agriculture compared to the cooler central highland region, the output of which is expected to remain the same or even increase with rising temperatures [63]. The pace of climate change determines its impact, thereby determining the cost of adjustment, so environmental policies must be dynamic and implemented with adaptation and flexibility [64].

A sensitivity analysis using CERES (crop estimation through resources and environmental synthesis) has also shown that wheat and rice yields in northwest India have the potential to increase by $28 \%$ and $15 \%$, respectively, at double the levels of $\mathrm{CO}_{2}$; however, the increased thermal stress due to elevated level of temperatures associated with high $\mathrm{CO}_{2}$ nearly cancels out the positive impact. Moreover, there will be an increased yield in both rice and wheat by $21 \%$ and $4 \%$, respectively, if the irrigation scheduling followed at present is practiced even under the combined effect of enhanced $\mathrm{CO}_{2}$ and thermal stress. But in case of acute water shortage along with thermal stress, the yield of rice and wheat is projected to decline even under the positive influence of raised $\mathrm{CO}_{2}$ in the future [65]. The increased $\mathrm{CO}_{2}$ concentration has the potential to offset the losses in the crop yields due to rising temperatures and reduced soil moisture [66]. The raised $\mathrm{CO}_{2}$ concentration considerably reduces the global yield losses by mainly decreasing agricultural consump- 
tive water use (4-17\%). Moreover, the crop yields' regional differences are mostly due to different crops' growing environments [67]. The concentration of nutrients $(\mathrm{N}, \mathrm{Fe}, \mathrm{Zn}$, and S) mainly found in proteins is reduced in non-leguminous $C_{3}$ crops with an elevated level of $\mathrm{CO}_{2}$ [68]. At the increased level of $\mathrm{CO}_{2}$, enhanced vegetative and reproductive growth and enhanced seed yield are observed in rice crops at an ambient air temperature of $29^{\circ} \mathrm{C}$; however, with increased temperature, the seed set was decreased [69].

At an elevated level of $\mathrm{CO}_{2}$, the zinc and iron content of $\mathrm{C}_{3}$ grain crops and legumes are decreasing, which has detrimental effects on human health. $C_{3}$ plants and legumes' protein concentration is also observed to be lowered, while $\mathrm{C}_{4}$ plants are unaffected by a raised $\mathrm{CO}_{2}$ level [70]. The changes in climate also impact the microbial population present in the soil, and their enzymatic activities. When assessed from a temperaturegradient tunnel with a $4-5{ }^{\circ} \mathrm{C}$ higher temperature, the microbial population was found to be significantly higher than in field conditions. The population of nitrogen-fixing and P-solubilizers bacteria and fungus, as well as enzymatic activities, were significantly higher under a wide range of temperatures, but the highest parameters were found on or near the optimum temperature [71]. In contrast, the growth of endophytic fungus and plantgrowth-promoting bacteria has a positive, negative, or neutral impact, depending on the temperature range [72]. The impact of climate change on various crops' productivity as estimated through various models is shown in Table 1. 
Table 1. Impact of climate change on crop productivity.

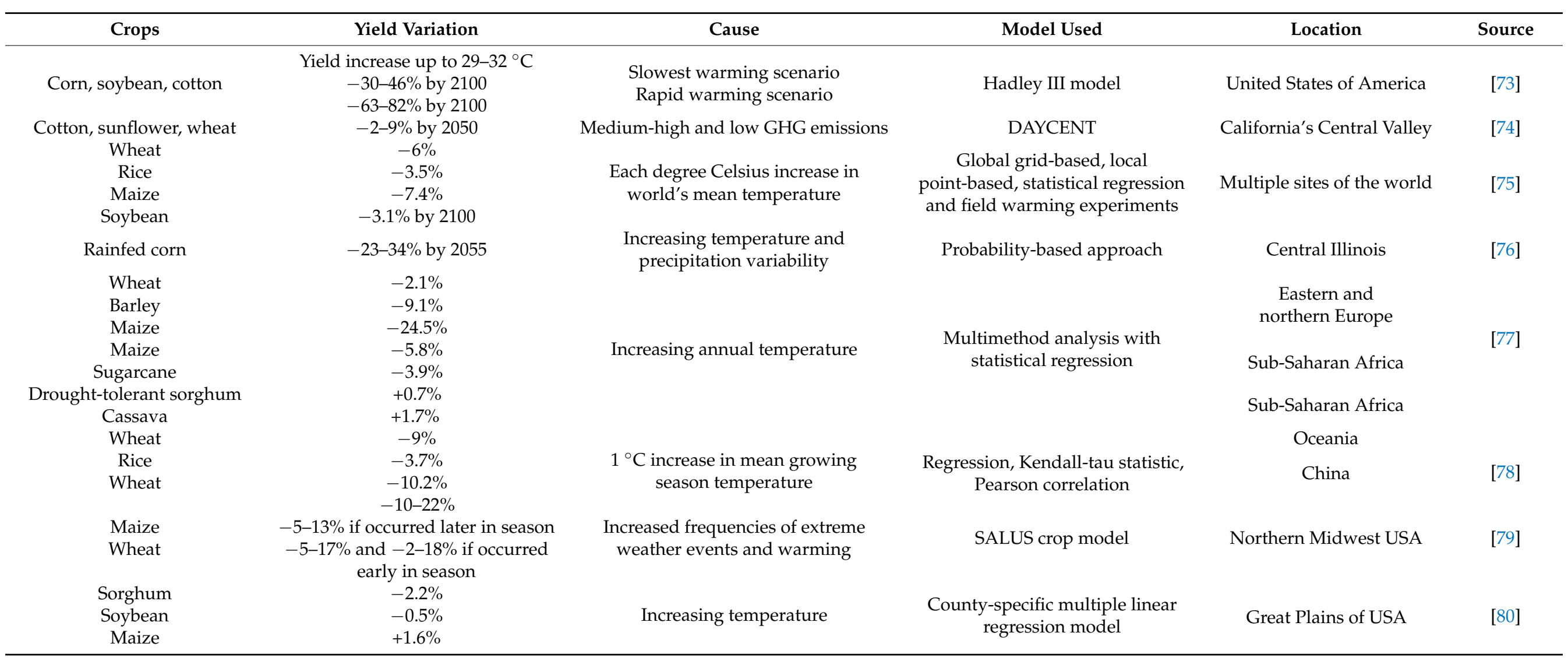


Projected changes in climate are most likely to affect the development and survival of pathogens [81]. The change in climate or weather pattern of an area is predicted to increase a crop's susceptibility to various pests, diseases, and weeds. Increased yields are projected in countries of high and mid-latitudes, while yields are projected to decrease at lower latitudes [82]. However, there are projections of a $10-25 \%$ increase in losses due to insect pest infestation with an increased temperature of one degree [83]. Climate change has the potential to increase the pest population and its migration, which can have an adverse impact on agricultural yields and even viability, as the pest population depends mainly on abiotic factors such as humidity and temperature. In Brazil, the infestation of coffee nematodes and leaf miners is expected to increase due to an increase in the number of generations in a month compared to the climatic conditions of 1961-1990 [84]. Pest infestation thereby has led to huge pesticides costs for pest management. There is statistical evidence that increased rainfall and temperatures increased the costs of pesticides for crops such as corn, potatoes, and soybean, in contrast to a reduction in wheat in the USA [85]. The ratio of arable land affected by the European corn borer and the Colorado potato beetle is expected to increase by 43 and $48 \%$, respectively, for the second generations in HadCM3-high 2050 scenario, and the unoccupied areas of high altitudes are also found vulnerable to these pests in the scenario of increasing temperature in Central Europe [86]. In the current global-warming scenario, an expansion of the suitable areas for wheat aphid (Schizaphis graminum) has been predicted to upper latitudes in northern hemisphere by 2030 while in northern hemisphere, the area is predicted to contract [87]. The frequency of the insect outbreak of 30 pest species is also expected to rise. It is likely to affect new areas with the increasing temperature in Sweden and affect its forestry sector [88]. The future projection of the potato tuber moth (Phthorimaea operculella) when done through GIS modeling, reported an estimated increase in the pest's damage potential in tropical and subtropical warmer regions, where the pest already prevails. It is also predicted to expand in temperate and mountainous regions, with a slightly increased damage potential [89].

The life cycle of pathogens such as Puccinia striiformis f.sp. trictici is projected to be limited by increasing temperature, while an increase in the concentration of atmospheric $\mathrm{CO}_{2}$ is estimated to provide advantageous conditions for Fusarium pseudograminearum [90]. Climate change impacts the geographical distribution and growth rate of populations, along with increasing the number of generations. Climate change can extend the development season of the pests and change the synchronization of crop and pest. It can also increase the risk of migrant pest invasion. The efficiency of plant protection measures such as host plant resistance, natural enemies, transgenic plants, synthetic chemicals, or biopesticides are also likely to be reduced due to climate change [91]. There could be unpredictable interactions of cropping systems, weather, and pests due to climate change and globalization [92]. Climate change is likely to impact insects' growth and their metabolic rates, particularly in temperate regions [55]. The region of suitability of pest infestation is also increasing because of climate change. The three common insect species of Africa, Tuta absoluta, Ceratitis cosyra, and Bactrocera invadens, have increasing habitat suitability across the entire continent, particularly in regions close to its most suitable habitat [93]. Moreover, the increased $\mathrm{CO}_{2}$ level and the rising temperature are increasing the threat of late blight of potato, blast, and sheath blight of rice, which could pose a serious threat to the world's food security [94].

Weed infestation of crops is also affected by climate change. $C_{3}$ weeds respond more strongly to an increase in $\mathrm{CO}_{2}$ concentration, with increased leaf area and biomass. $\mathrm{C}_{3}$ weeds are a major problem in $\mathrm{C}_{4}$ plants, while $\mathrm{C}_{4}$ weeds in $\mathrm{C}_{3}$ plants become less competitive [95]. Weeds compete with crops for water and nutrients, as they have higher nutrient requirements than the crop plants [96]. Climate change also influences the dynamics of crop-weed competition. Apart from weed growth, climate change also significantly influences herbicide efficacy, as it affects the herbicidal mode of action [97]. Climate change is projected to have a favorable influence on the weeds of wheat crops, which are very vital to world food security [98]. In the wake of climate change, new geographical horizons are being opened up for weeds, and their management can only be possible if new manage- 
ment practices are being planned while considering climate change. Pest infestations of various crops is predicted to worsen with climate change, as warmer and humid conditions are more favorable to pest proliferation. However, it will vary from region to region and according to the pests' adaptability to climate change.

\section{Mitigation and Adaptation to Climate Change}

Farmers' perceptions of climate change's threat and severity have the most important motivational factor in voluntary mitigation. However, the adaptation depends on the availability of related information [99]. Moreover, there will be a reduction in the number of people exposed to water stress with mitigation strategies, but the remaining people will need adaptation strategies due to their exposure to increased stress [100]. The usage of traditional management systems and agroecological management systems, namely biodiversification, soil management, and water harvesting, can help farmers adopt climate-resilient technologies [101]. These management practices ensure increased carbon sequestration, increased soil health, increased soil quality and reduced soil erosion, leading to resilient soils and cropping systems, ultimately ensuring food security during climate change [102]. These educational interventions, which focus on local, tangible, and actionable aspects, and could be monitored by individual behavior, are the most successful in providing climate-change education for ecological development [103]. The farmers were basically in support of adaptations, but the GHG reduction is endorsed by only a few, which shows the need to focus on interventions having both the features of adaptation and mitigation [104,105]. The main adaptation methods of mitigation can be broadly classified into resource-conservation technologies, cropping-system technologies, and socio-economic or policy interventions [106]. Small and marginal farmers are not able to cope with climate change due to less awareness, which makes them more susceptible to losses [28]. The farmers of African countries are also very vulnerable to climate change due to financial implications and lack of management strategies [93]. There have been ways to curb the impact of climate change by a number of agronomic practices, such as a shift in sowing dates. The optimum sowing dates for wheat have been identified as October 22-28 in the northeastern part, October 24-30 in the central region, and October 21-27 in the southwestern region of Punjab, India [107]. The yield loss of the crops is lowest when the farmers have adopted sequential cropping systems in sub-Saharan Africa, and adjust the sowing dates according to climate [108]. The agroforestry sector can mitigate GHG accumulation in the atmosphere, and thus help small farmers of Kenya adapt to climate change. There are certain simple approaches to decreasing GHG emissions, such as alternate drying in rice, mid-season drainage, improved livestock diet, increasing $\mathrm{N}$-use efficiency, and soil carbon. Simple adaptation strategies like changing planting dates and varieties have the potential to decrease the impact of climate change [109]. Diffusion of technology is very important in shaping the response of farmers to climate change. The main priority areas are market integration and support of public research and capacity-building [110].

Conservation agriculture has the potential to reverse the degradation caused by conventional tillage over the years, as it leads to minimum soil disturbance, crop diversity, and maintenance of soil cover. Moreover, conservation agriculture leads to lower GHG emissions, reduced fertilizer use, and higher terrestrial carbon sequestration [111]. Minimum soil disturbance, crop rotation, and soil cover are the underlying principles of conservation agriculture that pave sustainable agriculture methods. In south Asia, farmers are adopting zero tillage for wheat cultivation primarily because of a $15-16 \%$ reduction in cultivation cost. Moreover, zero tillage leads to higher yields with lesser variability in wheat and maize [112]. No-till practices were also claimed as an alternative to conventional tillage, which mitigates the impact of climate change through carbon sequestration; however, its impact in the mitigation of climate change is exaggerated, as the additional organic carbon in no-till cultivation is very small [113]. There have been various factors responsible for the adoption of conservation agriculture (CA), namely perception of individual benefits, functional market exchange techniques to supply the mandatory resources for CA im- 
plementation, economic motivation for farmers, development of farmer organizations to encourage local adaptation, and the creation of a suitable environment by alliances of farmer organizations and institutions [114].

The means to adapt to climate change are mainly modified farm practices, and are influenced greatly by the policy decisions suiting the climatic variability and climate extremes, along with social, political, and economic conditions [115]. The conventional intensification of agriculture causes huge economic losses, out of which almost $80 \%$ are caused by mismanagement of nutrients, which makes nutrient management an important aspect [116]. Carbon sequestration, or an increase in soil organic carbon (SOC), can be encouraged by no-till farming, cover crops, manuring, nutrient management, agroforestry, and soil restoration. Moreover, carbon sequestration can reduce $5-15 \%$ of fossil-fuel emissions globally [117]. Direct-seeded rice (DSR) causes fewer GHG emissions compared to transplanted rice. Dry DSR and wet DSR have $76.2 \%$ and $60.4 \%$ lower potential for global warming, respectively, in comparison to transplanted rice. Moreover, wet DSR also produced a $10.8 \%$ higher yield than transplanted rice [118].

Aerobic rice also has a huge potential in the mitigation of future climate change, as it saves $73 \%$ of irrigation water used in land preparation and $56 \%$ water used in the period of crop growth. Cultivation of aerobic rice by using micro-irrigation technologies is a suitable method for sustainable rice production. It also helps in reducing methane emission from rice fields [119]. There could be possible shortage of fresh water available for irrigation in the western US, China, and south, west and central Asia, which could lead to the conversion of 20-60 million ha of irrigation area to rainfed area, and cause a loss of 600-2900 pcal in food production [120]. Drip irrigation is one of the irrigation techniques being promoted to reduced groundwater overdraft and shocks induced by climate change. It has the potential to be resilient to climate change, and reduces the demand of groundwater for irrigation. But farmers are using drip irrigation for intensive agriculture, leading to further groundwater overextraction, causing Jevons paradox [121]. Water-saving irrigation techniques such as sprinkler irrigation and drip irrigation can help mitigate and adapt to climate change, and provide sustained economic benefits. However, the incremental cost of mitigation in sprinkler irrigation is reported to be highest i.e., USD 476.03-691.64/t due to water-pressure requirements, which could add to GHG emissions [122].

Agricultural practices based on site-specific information can help in reduced $\mathrm{N}$ application without lowering profitability. Precision agriculture is therefore considered more profitable than management of whole field [123]. In northwestern India, inefficient fertilizer management by farmers has led to lower nitrogen use efficiency. A leaf color chart (LCC) was found very suitable to improve the time and fertilizer rate. Upon application of fertilizers, when the LCC showed less than 4 shade, the produced rice yield was on par with the recommended blanket dose of $120 \mathrm{Kg} \mathrm{N} / \mathrm{ha}$ [124]. Application of fertilizers in rice at LCC $\leq 4$ decreased methane and nitrous oxide emissions by $11 \%$ and $16 \%$, respectively, over conventional $\mathrm{N}$ fertilizer application in split doses. In wheat, it led to $18 \%$ lower nitrous oxide emissions compared to conventional $\mathrm{N}$ fertilizer application [125]. Adoption of laser land leveling (LLL) has led to increased crop yields and farmer income. In the Raichur district of Karnataka, it was reported that LLL has raised the yield of paddy crops by 0.5 metric tons/ha, which can led to an upsurge in net farm income of INR 5000/annum. It has also reduced cultivation costs and confined the losses caused due to climatic variability [126]. Breeding of plants to form new varieties can be one way to cope with environmental stresses. This will require germplasm selection, shortening of breeding cycles, and multilocation trials to test a variety's suitability to the target environment $[127,128]$. As climate change is predicted to increase the frequency and intensity of abiotic stress, it is important to generate stress-tolerant varieties as a mitigation strategy. The cloning of the SUB1A gene in rice plants has facilitated the incorporation of the gene into various highyield varieties released in South Asian countries. These submergence-tolerant varieties produce a higher yield than the original varieties after being submerged for 18 days [129]. Climate smart agriculture (CSA) aims to adapt to climate change by adopting several 
interventions, including water-smart practices, nutrient-smart practices, weather-smart activities, carbon-smart activities, and knowledge-smart activities. Climate-smart agriculture builds resilience to climate change by building evidence, enhancing local institutions' effectiveness, promoting agricultural policies according to climate, and linking agricultural financing to climate [130].

Most efficient climate-smart technologies are those which either provide nutrients or water, or support soil structure. In semiarid West Africa, some technologies, namely half-moons, stone bunds and zai, and nutrient application were found suitable for maintaining food production and securing smallholder farmers [131]. Climate-smart agriculture technologies were studied in Punjab, Pakistan, and a higher productivity of cotton with higher returns and higher resource-use efficiency was observed [132]. The Indo-Gangetic plain is very vulnerable to climate change, which has adverse effects on the rice-wheat cropping of the area. Farmers have expressed their willingness to adopt climate-smart agriculture technologies that can transform conventional agricultural practices into more productive technologies. Laser land leveling (LLL), weather-advisory services, and crop insurance are the most-preferred CSA technologies of the eastern indo-gangetic plains (IGP), while the farmers of the western IGP mainly prefer direct seeding, LLL, zero tillage, crop insurance, and irrigation scheduling [133]. These mitigation strategies have huge mitigation and adaptation potentials. However, they depend upon the suitability of a technology to the region, people's perception, economic viability, and technical complexity. Moreover, these strategies work well when a number of interventions are used together in solidarity with each other.

\section{Economic Impact of Climate Change and Climate-Smart Agriculture Technologies}

Climate change has initially had certain positive impacts, but the environment's unavoidable warming is a negative externality. A rise in temperature beyond $3{ }^{\circ} \mathrm{C}$ has net negative results, and more than $7^{\circ} \mathrm{C}$ can cause total welfare loss. The world's social cost of carbon emission is expected to be USD 29/tC (tonnes of Carbon) in 2015, and to raise at $2 \%$ per year [134]. The net economic gains in the fishery sector of Solomon Island would be considerable if mitigation strategies for climate change are adopted. Climate change also will severely affect agricultural markets, causing a reduction of $0.26 \%$ in global GDP [135]. There would be a projected annual loss of $0.2-1 \%$ in household welfare if the climate predicted for the 2080s occurred today [136] Both market and non-market damages increase in quadratic progression and are expected to cost $1.2 \%$ of GDP with a $1{ }^{\circ} \mathrm{C}$ increase in mean global temperature [137]. If future mitigation strategies follow the adaptation of strategies used in the past, global income is projected to show a $23 \%$ decrease by 2100 and a wider gap in income inequality [138]. Global economic growth is projected to be reduced by $0.28 \%$ per year [139]. The economic benefits of various climate-smart agriculture technologies can be seen in Table 2. 
Table 2. Incremental benefits of climate-smart agriculture technologies.

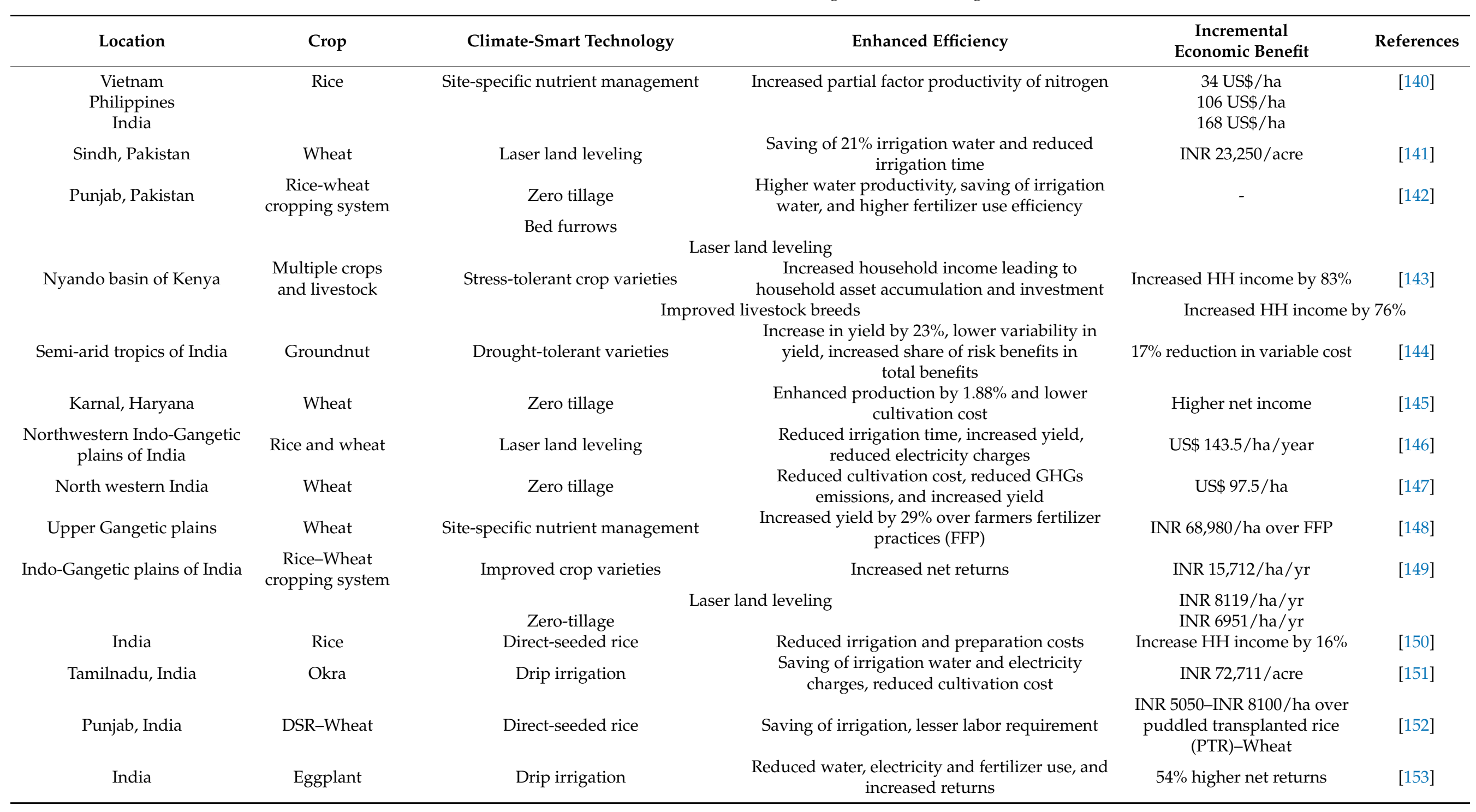




\section{Conclusions and Prospects}

An increasing population has put a lot of pressure on agriculture to ensure the food and nutritional security of the world, which is further worsening with climate change. Even though there are uncertainties regarding the future climate scenario and its possible impacts, various studies report that climate change will decrease agricultural productivity in the coming years. The key factors of climate, namely temperature, precipitation, and greenhouse gases, significantly hampered pest infestation, soil fertility, irrigation resources, physiology, and plants' metabolic activities. A number of mitigation and adaptation strategies have been developed to offset the deleterious impact of climate change on agricultural sustainability. These technologies include water-smart practices (laser land leveling, rainwater harvesting, micro-irrigation, crop diversification, raised-bed planting, direct-seeded rice), nutrient-smart practices (precision nutrient application, leaf color charts, crop residue management), weather-smart activities (stress-tolerant varieties, ICTbased agrometeorological services), carbon-smart activities (zero tillage, legumes, crop residue management) and knowledge-smart activities (agricultural extensions to enhance capacity-building). These technologies significantly reduce the effects of climate change on crops, and make them more suited to the climate by minimizing the unfavorable impacts. Climate change is predicted to cause huge economic losses at both the micro and macro levels that can be mitigated through these interventions. But these interventions must be organized at the regional or local level to improve their efficacy. Mitigation and adaptation strategies are expected to increase farmers' income without compromising agriculturalproduction sustainability. The future of climate change and its associated impacts is highly unpredictable, which makes planning for mitigation and adaptation a bit complex. This necessitates the formulation of climate-resilient technologies involving an interdisciplinary approach according to the region. Suitable varieties need to be developed that could adapt to climatic variations, along with planned agronomic management and crop pest control. Farmers need to be educated regarding various climate-smart technologies, and be provided training to simplify their use at the field level.

Keynotes:

1. Greenhouse-gas emissions at the global level are raising the $\mathrm{CO}_{2}$ content in the atmosphere, raising the global temperature due to greenhouse effect. However, landmasses have witnessed a higher increase in temperature than oceans.

2. The precipitation scenario is altered, and more weather extremes are projected to be witnessed in the near future.

3. Climate change is projected to have a deleterious impact on agricultural productivity. The raised temperature and altered precipitation are most likely to offset the positive impact of increased $\mathrm{CO}_{2}$ on plants.

4. The warmer and humid climate created due to climate change is creating more horizons for pest infestations.

5. Those climate-resilient technologies that are technically sound and economically viable must be framed using an interdisciplinary approach to mitigate climate change.

Author Contributions: P.K. conceived of and designed the project; P.K. supervised the study; G.S.M. and M.K. wrote the paper; P.K. checked and corrected the final draft. All authors have read and agreed to the published version of the manuscript.

Funding: This research received no external funding.

Institutional Review Board Statement: Not applicable.

Informed Consent Statement: Not applicable.

Data Availability Statement: Not applicable.

Acknowledgments: The authors are thankful to the anonymous reviewers for their careful read.

Conflicts of Interest: The authors declare that no conflict of interest exist. 


\section{References}

1. World Meteorological Organization. International Meteorological Vocabulary, 2nd ed.; WMO: Geneva, Switzerland, 1992.

2. IPCC. Climate change 2007: Impacts, adaptation and vulnerability. In Working Group II Contribution to the Fourth Assessment Report of the Intergovernmental Panel on Climate Change; Cambridge University Press: Cambridge, UK, 2007.

3. IPCC. Climate Change 2014: Synthesis Report; Pachauri, R.K., Meyer, L.A., Eds.; Contribution of Working Groups I, II and III to the Fifth Assessment Report of the Intergovernmental Panel on Climate Change; IPCC: Geneva, Switzerland, 2014; 151p.

4. Sathaye, J.; Shukla, P.R.; Ravindranath, N.H. Climate change, sustainable development and India: Global and national concerns Curr. Sci. 2006, 90, 314-325.

5. Abeydeera, L.H.U.W.; Mesthrige, J.W.; Samarasinghalage, T.I. Global research on carbon emissions: A scientometric review. Sustainability 2019, 11, 3972. [CrossRef]

6. NASA Earth Observatory. Goddard Space Flight Centre United States. Available online: www.earthobservatory.nasa.gov (accessed on 15 May 2020).

7. Arora, M.; Goel, N.K.; Singh, P. Evaluation of temperature trends over India/ Evaluation de tendances de temperature en Inde. Hydrol. Sci. J. 2005, 50, 81-93. [CrossRef]

8. NOAA. Earth System Research Laboratory (NOAA). 2020. Available online: www.esrl.noaa.gov (accessed on 15 December 2020).

9. CDIAC. Carbon Dioxide Information Analysis Center. 2020. Available online: www.cdiac.ess-dive.lbl.gov (accessed on 13 November 2020).

10. Tol, R.S.J. The economic impact of climate change in the 20th and 21st centuries. Clim. Chang. 2013, 117, 795-808. [CrossRef]

11. Our World in Data. Available online: www.ourworldindata.org (accessed on 4 December 2020).

12. Richie, H.; Roser, M. Our World in Data. CO2 and Greenhouse Emissions. 2017. Available online: https://ourworldindata.org/ co2-and-other-greenhouse-gas-emissions (accessed on 12 November 2020).

13. Wei, T.; Yang, S.; Moore, J.C.; Shi, P.; Cui, X.; Duan, Q.; Xu, B.; Dai, Y.; Yuan, W.; Wei, X.; et al. Developed and developing world responsibilities for historical climate change and $\mathrm{CO}_{2}$ mitigation. Proc. Natl. Acad. Sci. USA 2012, 109, 12911-12915. [CrossRef]

14. Hare, B.; Meinshausen, M. How much warming are we committed to and how much can be avoided? Clim. Chang. 2006, 75, 111-149. [CrossRef]

15. NCDC. National Climatic Data Center-National Center for Environmental Information (NOAA). 2020. Available online: www. ncdc.noaa.gov (accessed on 11 December 2020).

16. Bokhari, S.A.A.; Rasul, G.; Ruane, A.C.; Hoogenboom, G.; Ahmad, A. The past and future changes in climate of the rice-wheat cropping zone in Punjab, Pakistan. Pak. J. Meteorol. 2017, 13, 9-23.

17. Kaur, N.; Kaur, P. Projected climate change under different scenarios in central region of Punjab, India. J. Agrometeorol. 2016, 18, 88-92.

18. Chen, H.; Sun, J. Projected changes in climate extremes in China in a 1.5C warmer world. Int. J. Climatol. 2018, 38, 3607-3617. [CrossRef]

19. Rajbhandari, R.; Shrestha, A.B.; Kulkarni, A.; Patwardhan, S.K.; Bajracharya, S.R. Projected changes in climate over the Indus river basin using a high resolution regional climate model (PRECIS). Clim. Dyn. 2015, 44, 339-357. [CrossRef]

20. Ning, L.; Riddle, E.E.; Bradley, R.S. Projected changes in climate extremes over the Northeastern United States. J. Climate 2015, 28, 3289-3310. [CrossRef]

21. Zhang, Y.G.; Nearing, M.A.; Zhang, X.C.; Xie, Y.; Wei, H. Projected rainfall erosivity changes under climate change from multimodel and multiscenario projections in Northeast China. J. Hydrol. 2010, 384, 97-106. [CrossRef]

22. Zaveri, E.; Russ, J.; Damania, R. Rainfall anomalies are a significant driver of cropland expansion. Proc. Natl. Acad. Sci. USA 2020, 117, 10225-10233. [CrossRef]

23. Betts, R.A.; Alfieri, L.; Bradshaw, C.; Caeser, J.; Feyen, L.; Friedlingstein, P.; Gohar, L.; Koutroulis, A.; Lewis, K.; Morfopoulos, C.; et al. Changes in climate extremes, fresh water availability and vulnerability to food insecurity projected at $1.5^{\circ} \mathrm{C}$ and $2{ }^{\circ} \mathrm{C}$ global warming with a higher-resolution global climate model. Phil. Trans. R. Soc. A 2018, 376, 20160452. [CrossRef] [PubMed]

24. World Population Review. Walnut, United States. Available online: www.worldpopulationreview.com (accessed on 12 May 2020).

25. Alexandratos, N.; Bruinsma, J. World Agriculture: Towards 2030/2050; ESA Working Paper No. 12-03; FAO: Rome, Italy, 2012.

26. Lobell, D.B.; Schlenker, W.; Costa-Roberts, J. Climate trends and global crop production since 1980. Science 2011, 333, 616-620. [CrossRef]

27. Malhi, G.S.; Kaur, M.; Kaushik, P.; Alyemeni, M.N.; Alsahli, A.; Ahmad, P. Arbuscular mycorrhiza in combating abiotic stresses in vegetables: An eco-friendly approach. Saudi J. Biol. Sci. 2020. [CrossRef]

28. Baul, T.K.; McDonald, M. Integration of Indigenous knowledge in addressing climate change. Indian J. Tradit. Knowl. 2015, 1, 20-27.

29. Moher, D.; Liberati, A.; Tetzlaff, J.; Altman, D.G. The prisma group. Preferred reporting items for systematic reviews and meta-analyses: The PRISMA statement. Int. J. Surg. 2010, 8, 336-341.

30. Fargnoli, M.; Lombardi, M. Safety vision of Agricultural tractors: An engineering perspective based on recent studies (2009-2019). Safety 2020, 6, 1. [CrossRef]

31. Stern, D.I.; Kaufmann, R.K. Anthropogenic and natural causes of climate change. Clim. Chang. 2014, 122, 257-269. [CrossRef]

32. Montzka, S.A.; Dlugokencky, E.J.; Butler, J.H. Non- $\mathrm{CO}_{2}$ greenhouse gases and climate change. Nature 2011, 476, 43-50. [CrossRef] [PubMed] 
33. Groenigen, K.J.V.; Osenberg, C.W.; Hungate, B.A. Increased soil emissions of potent greenhouse gases under increased atmospheric $\mathrm{CO}_{2}$. Nature 2011, 475, 214-216. [CrossRef] [PubMed]

34. Popp, A.; Lotze-Campen, H.; Bodirsky, B. Food consumption, diet shifts and associated non- $\mathrm{CO}_{2}$ greenhouse gases from agricultural production. Glob. Environ. Chang. 2010, 20, 451-462. [CrossRef]

35. O'Mara, F.P. The significance of livestock as a contributor to global greenhouse gas emissions today and in the near future. Anim. Feed Sci. Technol. 2011, 166-167, 7-15. [CrossRef]

36. Lesschen, J.P.; Berg, M.V.D.; Westhoek, H.J.; Oenema, O. Greenhouse gas emission profiles of European livestock sectors. Anim. Feed Sci. Technol. 2011, 166-167, 16-28. [CrossRef]

37. Kahrl, F.; Li, Y.; Su, Y.; Tennigkeit, T.; Wilkes, A.; Xu, J. Greenhouse gas emissions from nitrogen fertilizer use in China. Environ. Sci. Policy 2010, 13, 688-694. [CrossRef]

38. Soltani, A.; Rajabi, M.H.; Zeinali, E.; Soltani, E. Energy inputs and greenhouse gases emissions in wheat production in Gorgan, Iran. Energy 2013, 50, 54-61. [CrossRef]

39. Mendelsohn, R. The impact of climate change on agriculture in developing countries. J. Nat. Res. Policy Res. 2009, 1, 5-19. [CrossRef]

40. Adams, R.M.; Hurd, B.H.; Lenhart, S.; Leary, N. Effects of global climate change on agriculture: An interpretative review. Clim. Res. 1998, 11, 19-30. [CrossRef]

41. Karimi, V.; Karimi, E.; Keshavarz, M. Climate change and agriculture: Impacts and adaptive responses in Iran. J. Integr. Agric. 2018, 17, 1-15. [CrossRef]

42. Molua, E.L.; Lambi, C.M. The Economic Impact of Climate Change on Agriculture in Cameroon; Policy Research Working Paper; The World Bank: Washington, DC, USA, 2007; pp. 1-31.

43. Gay, C.; Estrada, F.; Conde, C.; Eakin, H.; Villers, L. Potential impacts of climate change on Agriculture: A case of study of coffee production in Veracruz, Mexico. Clim. Chang. 2006, 79, 259-288. [CrossRef]

44. Kang, Y.; Khan, S.; Ma, X. Climate change impacts on crop yield, crop water productivity and food security-A review. Prog. Nat. Sci. 2009, 19, 1665-1674. [CrossRef]

45. Mahato, A. Climate change and its impact on agriculture. Int. J. Sci. Res. Publ. 2014, 4, 1-6.

46. Challinor, A.J.; Watson, J.; Lobell, D.B.; Howden, S.M.; Smith, D.R.; Chhetri, N. A meta-analysis of crop yield under climate change and adaptation. Nat. Clim. Chang. 2014, 4, 287-291. [CrossRef]

47. Rosenzweig, C.; Liverman, D. Predicted effects of climate change on agriculture: A comparison of temperate and tropical regions. In Global Climate Change: Implications, Challenges, and Mitigation Measures; Majumdar, S.K., Ed.; PA The Pennsylvania Academy of Sciences: Grove City, PA, USA, 1992; pp. 342-361.

48. Zhang, P.; Zhang, J.; Chen, M. Economic impacts of climate change on agriculture: The importance of additional climatic variables other than temperature and precipitation. J. Environ. Econ. Manag. 2017, 83, 8-31. [CrossRef]

49. Powell, J.P.; Reinhard, S. Measuring the effects of extreme weather events on yields. Weather Clim. Extrem. 2016, 12, 69-79. [CrossRef]

50. Li, Y.; Ye, W.; Wang, M.; Yan, X. Climate change and drought: A risk assessment of crop-yield impacts. Clim. Res. 2009, 39, 31-46. [CrossRef]

51. Stevanovic, M.; Popp, A.; Campen, H.L.; Dietrich, J.P.; Muller, C.; Bonsch, M.; Schmitz, C.; Bodirsky, B.L.; Humpenoder, F.; Weindl, I. The impact of high-end climate change on agricultural welfare. Sci. Adv. 2016, 2, e1501452. [CrossRef]

52. Bosello, F.; Zhang, J. Assessing Climate Change Impacts: Agriculture; FEEM Working Paper No. 94.05; CMCC Research Paper No. 2; Elsevier: New York, NY, USA, 2005; Available online: https:/ /ssrn.com/abstract=771245 (accessed on 18 January 2021). [CrossRef]

53. Kumar, R.; Gautam, H.R. Climate change and its impact on agricultural productivity in India. J. Climatol. Weather Forecast. 2014, 2, 1-3. [CrossRef]

54. Shakoor, U.; Saboor, A.; Ali, I.; Mohsin, A.Q. Impact of climate change on agriculture: Empirical evidence from arid region. Pak. J. Agri. Sci. 2011, 48, 327-333.

55. Deutsch, C.A.; Tewksbury, J.J.; Tigchelaar, M.; Battisti, D.S.; Merrill, S.C.; Huey, R.B.; Naylor, R. Increase in crop losses to insect pests in a warming climate. Science 2018, 361, 916-919. [CrossRef] [PubMed]

56. Waha, K.; Muller, C.; Bondeau, A.; Dietrich, J.P.; Kurukulasuriya, P.; Heinke, J.; Lotze-Campen, H. Adaptation to climate change through the choice of cropping system and sowing date in sub-Saharan Africa. Glob. Environ. Chang. 2013, 23, 130-143. [CrossRef]

57. Dey, M.M.; Gosh, K.; Valmonte-Santos, R.; Rosegrant, M.W.; Chen, O.L. Economic impact of climate change and climate change adaptation strategies for fisheries sector in Solomon Islands: Implication for food security. Mar. Policy 2016, 67, 171-178. [CrossRef]

58. Reyer, C.P.O.; Leuzinger, S.; Rammig, A.; Wolf, A.; Bartholomeus, R.P.; Bonfante, A.; Lorenzi, F.D.; Dury, M.; Gloning, P.; Jaoude, R.A.; et al. A plant's perspective of extremes: Terrestrial plant responses to changing climatic variability. Glob. Chang. Biol. 2012, 19, 75-89. [CrossRef] [PubMed]

59. Gray, S.B.; Brady, S.M. Plant developmental responses to climate change. Dev. Biol. 2016, 419, 64-77. [CrossRef] [PubMed]

60. Cao, L.; Bala, G.; Caldeira, K.; Nemani, R.; Ban-Weiss, G. Importance of carbon dioxide physiological forcing to future climate change. Proc. Natl. Acad. Sci. USA 2010, 107, 9513-9518. [CrossRef] 
61. DaMatta, F.M.; Grandis, A.; Arenque, B.C.; Buckeridge, M.S. Impacts of climate changes on crop physiology and food quality. Food Res. Int. 2010, 43, 1814-1823. [CrossRef]

62. Aydinalp, C.; Cresser, M. The effects of global climate change on agriculture. Am. Eur. J. Agric. Environ. Sci. 2008, 3, 672-676.

63. Seo, S.N.; Mendelsohn, R.; Munasinghe, M. Climate change and agriculture in Sri Lanka: A Ricardian valuation. Environ. Dev. Econ. 2005, 10, 581-596. [CrossRef]

64. Zilberman, D.; Liu, X.; Holst, D.R.; Sunding, D. The economics of climate change in agriculture. Mitig. Adapt. Strateg. Glob. Chang. 2004, 9, 365-382. [CrossRef]

65. Lal, M.; Singh, K.K.; Rathore, L.S.; Srinivasan, G.; Saseendram, S.A. Vulnerability of rice and wheat yields in NW India to future changes in climate. Agric. For. Meteorol. 1998, 89, 101-114. [CrossRef]

66. Long, S.P.; Ainsworth, E.A.; Leakey, A.D.B.; Nosberger, J.; Ort, D.R. Food for thought: Lower-than-expected crop yield stimulation with rising $\mathrm{CO}_{2}$ concentrations. Science 2006, 312, 1918-1921. [CrossRef] [PubMed]

67. Deryng, D.; Elliott, J.; Folberth, C.; Muller, C.; Pugh, T.A.M.; Boote, K.J.; Conway, D.; Ruane, A.C.; Gerten, D.; Jones, J.W.; et al. Regional disparities in the beneficial effects of rising $\mathrm{CO}_{2}$ concentrations on crop water productivity. Nat. Clim. Chang. 2016, 6, 786-790. [CrossRef]

68. Uddling, J.; Broberg, M.C.; Feng, Z.; Pleijel, H. Crop quality under rising atmospheric $\mathrm{CO}_{2}$. Curr. Opin. Plant Biol. 2018, 45, 262-267. [CrossRef] [PubMed]

69. Madan, P.; Jagadish, S.V.K.; Craufurd, P.Q.; Fitzgerald, M.; Lafarge, T.; Wheeler, T.R. Effect of elevated $\mathrm{CO}_{2}$ and high temperature on seed-set and grain quality of rice. J. Exp. Bot. 2012, 63, 3843-3852. [CrossRef]

70. Myers, S.S.; Zanobetti, A.; Kloog, I.; Huybers, P.; Leakey, A.D.B.; Bloom, A.J.; Carlisle, E.; Dietterich, L.H.; Fitzgerald, G.; Hasegawa, T.; et al. Increasing $\mathrm{CO}_{2}$ threatens human nutrition. Nature 2014, 510, 139-142. [CrossRef]

71. Kaur, J.; Gosal, S.K.; Kaur, P. Effects of climate change on plant associated microbial communities and enzyme activities. Afr. J. Microbiol. Res. 2014, 8, 3087-3093.

72. Compant, S.; Heijden, M.G.A.V.D.; Sessitsch, A. Climate change effects on beneficial plant-microorganism interactions. FEMS Microbiol. Ecol. 2010, 73, 197-214. [CrossRef]

73. Schlenker, W.; Roberts, M.J. Nonlinear temperature effects indicate severe damages to U.S. crop yields under climate change. Proc. Natl. Acad. Sci. USA 2009, 106, 15594-15598. [CrossRef]

74. Lee, J.; Gryze, S.D.; Six, J. Effect of climate change on field crop production in California's central valley. Clim. Chang. 2011, 109, S335-S353. [CrossRef]

75. Zhao, C.; Liu, B.; Piao, S.; Wang, X.; Lobell, D.B.; Huang, L.; Huang, M.; Yao, Y.; Bassu, S.; Clais, P.; et al. Temperature increase reduces global yields of major crops in four independent estimates. Proc. Natl. Acad. Sci. USA 2017, 114, 9326-9331. [CrossRef] [PubMed]

76. Cai, X.; Wang, D.; Laurent, R. Impact of climate change on crop yield: A case study of rainfed corn in Central Illinois. J. Appl. Meteorol. Climatol. 2009, 48, 1868-1881. [CrossRef]

77. Ray, D.K.; West, P.C.; Clark, M.; Gerber, J.S.; Prishchepov, V.; Chatterjee, S. Climate change has likely already affected global food production. PLoS ONE 2019, 14, e0217148. [CrossRef]

78. Tao, F.; Yokozawa, M.; Xu, Y.; Hayashi, Y.; Zhang, Z. Climate changes and trends in phenology and yields of field crops in China, 1981-2000. Agric. For. Meteorol. 2006, 138, 82-92. [CrossRef]

79. Liu, L.; Basso, B. Impacts of climate variability and adaptation strategies on crop yields and soil organic carbon in US Midwest. PLoS ONE 2020, 15, e0225433. [CrossRef]

80. Kukal, M.S.; Irmak, S. Climate-driven crop yield and yield variability and climate change impacts on the U.S. great plains agricultural production. Sci. Rep. 2018, 8, 1-18. [CrossRef]

81. Elad, Y.; Pertot, I. Climate change impact on plant pathogens and plant diseases. J. Crop Improv. 2014, 28, 99-139. [CrossRef]

82. Rosenzweig, C.; Iglesius, A.; Yang, X.B.; Epstein, P.R.; Chivian, E. Climate change and extreme weather events-Implications for food production, plant diseases, and pests. Glob. Chang. Human Health 2001, 2, 90-104. [CrossRef]

83. Shrestha, S. Effects of climate change in Agricultural Insect Pest. Acta Scient. Agric. 2019, 3, 74-80. [CrossRef]

84. Ghini, R.; Hamada, E.; Junior, M.J.P.; Marengo, J.A.; Goncalves, R.R.V. Risk analysis of climate change on coffee nematodes and leaf miner in Brazil. Pesqui. Agropecu. Braileira 2008, 43, 187-194. [CrossRef]

85. Chen, C.C.; McCarl, B.A. An investigation of the relationship between pesticide usage and climate change. Clim. Chang. 2001, 50, 475-487. [CrossRef]

86. Kocmankova, E.; Trnka, M.; Eitzinger, J.; Formayer, H.; Dubrovsky, M.; Semeradova, D.; Zalud, Z.; Juroch, J.; Mozny, M. Estimating the impact of climate change on the occurrence of selected pests in Central European region. Clim. Res. 2010, 44, 95-105. [CrossRef]

87. Aljaryian, R.; Kumar, L. Changing global risk of invading greenbug Schizaphis graminum under climate change. Crop Prot. 2016, 88, 137-148. [CrossRef]

88. Hof, A.R.; Svahlin, A. The potential effect of climate change on insect pest species' geographical distribution in the Swedish boreal forest. Scand. J. For. Res. 2015, 31, 1-15. [CrossRef]

89. Kroschel, J.; Sporleder, M.; Tonnang, H.E.Z.; Juarez, H.; Carhuapoma, P.; Gonzales, J.C.; Simon, R. Predicting climate-changecaused changes in global temperature on potato tuber moth Phthorimaea operculella (Zeller) distribution and abundance using phenology modeling and GIS mapping. Agric. For. Meteorol. 2013, 170, 228-241. [CrossRef] 
90. Luck, J.; Spackman, M.; Freeman, A.; Trebicki, P.; Griffiths, W.; Finlay, K.; Chakraborty, S. Climate change and diseases of food crops. Plant Pathol. 2011, 60, 113-121. [CrossRef]

91. Reddy, P.P. Impact of climate change on insect pests, pathogens and nematodes. Pest Manag. Hortic. Ecosyst. 2013, 19, $225-233$.

92. Lamichhane, J.R.; Barzman, M.; Booij, K.; Boonekamp, P.; Desneux, N.; Huber, L.; Kudsk, P.; Langrell, S.R.H.; Ratnadass, A.; Ricci, O.; et al. Robust cropping systems to tackle pests under climate change. A review. Agron. Sustain. Dev. 2015, 35, 443-459. [CrossRef]

93. Biber-Freudenberger, L.; Ziemacki, J.; Tonnang, H.E.Z.; Borgemeister, C. Future risks of pest species under changing climatic conditions. PLoS ONE 2016, 11, e0153237. [CrossRef]

94. Gautam, H.R.; Bhardwaj, M.L.; Kumar, R. Climate change and its impact on plant diseases. Curr. Sci. 2013, 105, $1685-1691$.

95. Korres, N.E.; Norsworthy, J.K.; Tehranchian, P.; Gitsopoulos, T.K.; Loka, D.A.; Oosterhuis, D.M.; Gealy, D.R.; Moss, S.R.; Burgos, N.R.; Miller, M.R.; et al. Cultivars to face climate change on crops and weeds: A review. Agron. Sustain Dev. 2016, 36, 12-22. [CrossRef]

96. Malhi, G.S.; Rana, M.C.; Rana, S.S.; Kaushik, P. Effect of individual or combined application of herbicide imazethapyr on nutrient uptake by blackgram (Vigna mungo L.). J. Exp. Biol. Agric. Sci. 2020, 8, 441-446. [CrossRef]

97. Varanasi, A.; Prasad, P.V.V.; Jugulam, M. Impact of climate change factors on weeds and herbicide efficacy. Adv. Agr. 2016, $135,108-138$.

98. Bajwa, A.A.; Farooq, M.; Al-Sadi, A.M.; Nawaz, A.; Jabran, K.; Siddique, K.H.M. Impact of climate change on biology and management of wheat pests. Crop Prot. 2020, 137, 105304. [CrossRef]

99. Semenza, J.C.; Ploubidis, G.B.; George, L.A. Climate change and climate variability: Personal motivation for adaptation and mitigation. Environ. Health 2011, 10, 1-12. [CrossRef]

100. Vuuren, D.P.V.; Issac, M.; Kundzewicz, Z.W.; Arnell, N.; Barker, T.; Criqui, P.; Berkhout, F.; Hilderink, H.; Hinkel, J.; Hof, A.; et al The use of scenarios as the basis for combined assessment of climate change mitigation and mitigation. Glob. Environ. Chang. 2010, 21, 575-591. [CrossRef]

101. Altieri, M.A.; Nicholls, C.I. The adaptation and mitigation potential of traditional agriculture in a changing climate. Clim. Chang. 2017, 140, 33-45. [CrossRef]

102. Lal, R.; Delgado, J.A.; Groffman, P.M.; Millar, N.; Dell, C.; Rotz, A. Management to mitigate and adapt to climate change. J. Soil Water Conserv. 2011, 66, 276-285. [CrossRef]

103. Anderson, A. Climate change education for mitigation and adaptation. J. Educ. Sustain. Dev. 2012, 6, 191-206. [CrossRef]

104. Arbuckle, J.G.; Morton, L.W.; Hobbs, J. Understanding farmer perspectives on climate change adaptation and mitigation: The roles of trust in sources of climate information, climate change beliefs, and perceived risk. Environ. Behav. 2015, 47, 205-234. [CrossRef]

105. Smith, P.; Olesen, J.E. Synergies between the mitigation of, and adaptation to, climate change in agriculture. J. Agric. Sci. 2010, 148, 543-552. [CrossRef]

106. Ventakeswarlu, B.; Shanker, A.K. Climate change and agriculture: Adaptation and mitigation strategies. Indian J. Agr. 2009, 54, 226-230.

107. Sandhu, S.S.; Kaur, P.; Gill, K.K.; Vashisth, B.B. The effect of recent climate shifts on optimal sowing windows for wheat in Punjab, India. J. Water Clim. Chang. 2019, 11, 1177-1190. [CrossRef]

108. Verchot, L.V.; Noordwijk, M.V.; Kandji, S.; Tomich, T.; Ong, C.; Albrecht, A.; Mackensen, J.; Bantilan, C.; Anupama, K.V.; Palm, C. Climate change: Linking adaptation and mitigation through agroforestry. Mitig. Adapt. Strat. Glob. Chang. 2007, 12, 901-918. [CrossRef]

109. Aggarwal, P.K. Global climate change and Indian agriculture: Impacts, adaptation and mitigation. Indian J. Agric. Sci. 2008, 78, 911-919.

110. Lybbert, T.J.; Sumner, D.A. Agricultural technologies for climate change in developing countries: Policy options for innovation and technology diffusion. Food Policy 2012, 37, 114-123. [CrossRef]

111. Pisante, M.; Stagnari, F.; Acutis, M.; Bindi, M.; Brilli, L.; Stefano, V.D.; Carozzi, M. Conservation agriculture and climate change. In Conservation Agriculture; Farooq, M., Siddique, K., Eds.; Springer: Cham, Switzerland, 2014. [CrossRef]

112. Erenstein, O.; Sayre, K.; Wall, P.; Hellin, J.; Dixon, J. Conservation agriculture in Maize and Wheat based systems in the (sub)tropics: Lessons from adaptation initiatives in South Asia, Mexico, and Southern Africa. J. Sustain. Agric. 2012, 36, 180-206. [CrossRef]

113. Powlson, D.S.; Stirling, C.M.; Jat, M.L.; Gerard, B.G.; Palm, C.A.; Sanchez, P.A.; Cassman, K.G. Limited potential of no-till agriculture for climate change mitigation. Nat. Clim. Chang. 2014, 4, 678-683. [CrossRef]

114. Brown, B.; Llewellyn, R.; Nuberg, I. Global learnings to inform the local adaptation of conservation agriculture in Eastern and Southern Africa. Glob. Food Sec. 2018, 17, 213-220. [CrossRef]

115. Smit, B.; Skinner, M.W. Adaptation options in agriculture to climate change: A typology. Mitig. Adapt. Strateg. Glob. Chang. 2002, 7, 85-114. [CrossRef]

116. Lu, Y.; Chadwick, D.; Norse, D.; Powlson, D.; Shi, W. Sustainable intensification of China's agriculture: The key role of nutrient management and climate change mitigation and adaptation. Agric. Ecosyst. Environ. 2015, 209, 1-4. [CrossRef]

117. Lal, R. Soil carbon sequestration impacts on global climate change and food security. Science 2004, 304, 1623-1627. [CrossRef] [PubMed] 
118. Tao, Y.; Chen, Q.; Peng, S.; Wang, W.; Nie, L. Lower global warming potential and higher yield of wet direct-seeded rice in Central China. Agron. Sustain. Dev. 2016, 36, 1-9. [CrossRef]

119. Parthasarathi, T.; Vanitha, K.; Lakshamanakumar, P.; Kalalyarasi, D. Aerobic rice-mitigating water stress for the future climate change. Int. J. Agr. Plant Prod. 2012, 3, 241-254.

120. Elliott, J.; Deryng, D.; Muller, C.; Frieler, K.; Konzmann, M.; Gerten, D.; Glotter, M.; Florke, M.; Wada, Y.; Best, N.; et al. Constraints and potentials of future irrigation water availability on agricultural production under climate change. Proc. Natl. Acad. Sci. USA 2014, 111, 3239-3244. [CrossRef]

121. Birkenholtz, T. Assessing India's drip-irrigation boom: Efficiency, climate change and groundwater policy. Water Int. 2017, 42, 663-677. [CrossRef]

122. Zou, X.; Li, Y.; Cremades, R.; Gao, Q.; Wan, Y.; Qin, X. Cost-effectiveness analysis of water-saving irrigation technologies based on climate change response: A case study of China. Agric. Water Manag. 2013, 129, 9-20. [CrossRef]

123. Bongiovanni, R.; Lowenberg-Deboer, J. Precision agriculture and sustainability. Precis. Agric. 2004, 5, 359-387. [CrossRef]

124. Singh, Y.; Singh, B.; Ladha, J.K.; Bains, J.S.; Gupta, R.K.; Singh, J.; Balasubramaniam, V. On-farm evaluation of leaf color chart for need-based nitrogen management in irrigated transplanted rice in northwestern India. Nutr. Cycl. Agroecosyst. 2007, 78, 167-176. [CrossRef]

125. Bhatia, A.; Pathal, H.; Jain, N.; Singh, P.K.; Tomer, R. Greenhouse gas mitigation in rice-wheat system with leaf color chart-based urea application. Environ. Monit. Assess. 2012, 184, 3095-3107. [CrossRef]

126. Pal, B.D.; Kapoor, S.; Saroj, S.; Jat, M.L.; Kumar, Y.; Anantha, K.H. Impact of Laser Land Leveling on Food Production and Farmers' Income: Evidence from Drought Prone Semi-Arid Tropics in India; IFPRI discussion paper 01960; IFPRI: Washington, DC, USA, 2020.

127. Atlin, G.N.; Cairns, J.E.; Das, B. Rapid breeding and varietal replacement are critical to adaptation of cropping systems in the developing world to climate change. Glob. Food Sec. 2017, 12, 31-37. [CrossRef] [PubMed]

128. Chhogyell, N.; Pradhan, N.; Ghimiray, M.; Bajgai, Y. Evaluation of short duration rice (Oryza sativa) varieties as a strategy to cope with climate change. Proc. Bhutan Ecol. Soc. 2016, 1, 91-103.

129. Gregorio, G.B.; Islam, M.R.; Vergara, G.V.; Thirumeni, S. Recent advances in rice science to design salinity and other abiotic stress tolerant rice varieties. SABRAO J. Breed. Genet. 2013, 45, 31-41.

130. Lipper, L.; Thornton, P.; Campbell, B.M.; Baedeker, T.; Brainmoh, A.; Bwalya, M.; Caron, P.; Cattaneo, A.; Garrity, D.; Henry, K.; et al. Climate-smart agriculture for food security. Nat. Clim. Chang. 2014, 4, 1068-1072. [CrossRef]

131. Zougmore, R.; Jalloh, A.; Tioro, A. Climate-smart soil water and nutrient management options in semiarid West Africa: A review of evidence and analysis of stone bunds and zai techniques. Agric. Food Sec. 2014, 3, 1-8. [CrossRef]

132. Imran, M.A.; Ali, A.; Ashfaq, M.; Hassan, S.; Culas, R.; Ma, C. Impact of climate smart agriculture (CSA) practices on cotton production and livelihood of farmers in Punjab, Pakistan. Sustainability 2018, 10, 2101. [CrossRef]

133. Taneja, G.; Pal, B.D.; Joshi, P.K.; Aggarwal, P.K.; Tyagi, N.K. Farmers' preferences for climate-smart agriculture-an assessment in the Indo-Gangetic plain. In Climate Smart Agriculture in South Asia; Pal, B., Kishore, A., Joshi, P., Tyagi, N., Eds.; Springer: Singapore, 2019. [CrossRef]

134. Tol, R.S.J. On the uncertainty about the total economic impact of climate change. Environ. Res. Econ. 2012, 53, 97-116. [CrossRef]

135. Costinot, A.; Donaldson, D.; Smith, C. Evolving comparative advantage and the impact of climate change in agricultural markets: Evidence from 1.7 million fields around the world. J. Pol. Econ. 2016, 124, 20-25. [CrossRef]

136. Ciscar, J.C.; Iglesias, A.; Feyen, L.; Szabo, L.; Regemorter, D.V.; Amelung, B.; Nicholls, R.; Watkiss, P.; Christensen, O.B.; Dankers, R.; et al. Physical and economic consequences of climate change in Europe. Proc. Natl. Acad. Sci. USA 2011, 108, $2678-2683$. [CrossRef]

137. Hsiang, S.; Kopp, R.; Jina, A.; Rising, J.; Delgado, M.; Mohan, S.; Rasmussen, D.J.; Muir-Wood, R.; Wilson, P.; Oppenheimer, M.; et al. Estimating economic damage from climate change in the United States. Science 2017, 356, 1362-1369. [CrossRef]

138. Burke, M.; Hsiang, S.M.; Miguel, E. Global non-linear effect of temperature on economic production. Nature 2015, 527, 235-239. [CrossRef] [PubMed]

139. Carleton, T.A.; Hsiang, S.M. Social and economic impacts of climate. Science 2016, 353, 9837. [CrossRef] [PubMed]

140. Pampolino, M.F.; Manguiat, I.J.; Ramanathan, S.; Gines, H.C.; Tan, P.S.; Chi, T.T.N.; Rajendran, R.; Buresh, R.J. Environmental impact and economic benfits of site-specific nutrient management (SSNM) in irrigated rice systems. Agric. Syst. 2007, 93, 1-24. [CrossRef]

141. Wagan, S.A.; Memon, Q.U.A.; Wagan, T.A.; Memon, I.H.; Wagan, A. Economic analysis of laser land leveling technology water use efficiency and crop productivity of wheat crop in Sindh, Pakistan. J. Environ. Earth Sci. 2015, 5, 21-25.

142. Latif, A.; Shakir, A.S.; Rashid, M.U. Appraisal of economic impact of zero tillage, laser land levelling and bed-furrow intervention in Punjab, Pakistan. Pak. J. Eng. Appl. Sci. 2013, 13, 65-81.

143. Ogada, M.J.; Rao, E.J.O.; Radeny, M.; Recha, J.W.; Solomon, D. Cllimate-smart agriculture, household income and asset accumulation among smallholder farmers in Nyando basin of Kenya. World Dev. Perspect. 2020. [CrossRef]

144. Birthal, P.S.; Nigam, A.N.; Narayanan, A.V.; Kareem, K.A. Potential economic benefits from adoption of improved droughttolerant groundnut in India. Agric. Econ. Res. Rev. 2012, 25, 1-14.

145. Tripathi, R.S.; Raju, R.; Thimmappa, K. Impacts of zero tillage on economics of wheat production in Haryana. Agric. Econ. Res. Rev. 2013, 26, 101-108. 
146. Aryal, J.P.; Mehrotra, M.B.; Jat, M.L.; Sidhu, H.S. Impacts of laser land leveling in rice-wheat systems of the north-western indo-gangetic plains of India. Food Sec. 2015. [CrossRef]

147. Aryal, J.P.; Sapkota, T.B.; Jat, M.L.; Bishnoi, J.K. On-farm economic and environmental impact of zero-tillage wheat: A case of north-west India. Expl. Agric. 2015, 51, 1-16. [CrossRef]

148. Singh, V.K.; Shukla, A.K.; Singh, M.P.; Majumdar, K.; Mishra, R.P.; Rani, M.; Singh, S.K. Effect of site-specific nutrient management on yield, profit and apparent nutrient balance under pre-dominant cropping systems of Upper Gangetic Plains. Indian J. Agric. Sci. 2015, 85, 335-343.

149. Khatri-Chhetri, A.; Aryal, J.P.; Sapkota, T.B.; Khurana, R. Economic benefits of climate-smart agricultural practices to smallholder farmers in the Indo-Gangetic Plains of India. Curr. Sci. 2016, 110, 1251-1256.

150. Mishra, A.K.; Khanal, A.R.; Pede, V. Economic and resource conservation perspectives of direct seeded rice planting methods: Evidence from India. In Proceedings of the Agricultural and Applied Economics Association's 2017 AAEA Annual Meeting, Chicago, IL, USA, 30 July-2 August 2016.

151. Narayanamoorthy, A.; Devika, N. Economic and resource impacts of drip method of irrigation on okra cultivation: An analysis of field survey data. J. Land Rural Stud. 2017, 6, 15-33. [CrossRef]

152. Bhullar, M.S.; Singh, S.; Kumar, S.; Gill, G. Agronomic and economic impacts of direct seeded rice in Punjab. Agric. Res. J. 2018, 55, 236-242. [CrossRef]

153. Narayanamoorthy, A.; Bhattarai, M.; Joshi, P. An assessment of the economic impact of drip irrigation in vegetable production in India. Agric. Econ. Res. Rev. 2018, 31, 105-112. [CrossRef] 